\title{
ARTICLE
}

\section{THREE SPECIES OF HETERODERMIA RECORDED IN MONGOLIA}

Enkhtuya O. * and Javkhlan S.

Laboratory of Flora and plant systematic, Institute of General and Experimental Biology Mongolian Academy of Sciences, Ulaanbaatar, Mongolia

\begin{abstract}
Heterodermia hypoleuca (Ach.) Treis.,H.japonica (M. Sato) Swinscow \& Krogand H. subascendens (Asahina) Trass. have been recorded for the first time in Mongolia. Data on substrates, habitats, distribution are listed for every species. Taxonomic comments and distinctive characters are provided for these species. The habitats are briefly described and the frequently associated species are listed. It is interesting to note that as a result of processing hundreds of herbarium collections of lichens, numerous new species were found in Mongolia. This means that there is still a substantial gap in the knowledge, especially about the lichen flora of remote corners of the country, which are numerous.
\end{abstract}

Keywords: lichen species; Heterodermia; Mountain Range; mossed granite rocks;

\section{INTRODUCTION}

Recently, as mentioned in the work of M. Hauck et all [11] the lichen flora of Mongolia is better known as compared to many other Central Asian countries or regions (Central Asia is treated here in a broad sense), like Kazakhstan [32], Kyrgyzstan [22], Tajikistan [19], Xinjiang [1] or Tibet [33]. According to the checklist of the mongolian lichens by Biazrov Lev G [5] there are 1067 lichens and 13 lichenicolous fungi now known in Mongolia. The small number of lichenicolous fungi registered so far is perhaps because of the limited investigation carried out into this group of fungi in Mongolia [14, 15, 16, 17]. This time, we present 3 species to be added to the lichen flora of Mongolia. Until recently only two species of Heterodermia such as $H$. leucomelos (L.) Poelt from willow bark [2] and $H$. speciosa (Wulfen in Jacq.) Trevis from mossy rock $[9,10,7,8,11]$ were known from a very few localities in Mongolia.

One of the main reasons for the poor knowledge of lichenised fungi and their ecology has been the lack of adequate Information about the taxomony of Physciaceae, Heterodermia species. In some cases, even frequent species had not been identified until recently. We hope that many unknown species are included in the herbarium material (UBA) of the Mongolian Academy of Sciences. 
The objective of the present work is to present a new species of Heterodermia of lichenised Ascomycetes and Physciaceae, newly discovered in Mongolia for the first time. Species identification of Heterodermia and Physciaceae were carried out basing on samples of lichens collected by the author in 1995 from Bogd Uul Mountain in the southern

\section{MATERIALS AND METHODS}

Lichens were collected from 2 locations during field trips in 1995 and 2013 respectively. The localities included vegetation forest of Picea ovobata Ldb., Betula fusca Fall. with granite rocks. Lichens were collected from these

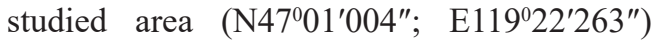
from the base trunks of bark Betula fusca Fall. and from (N 47 45'49.9"; E $107^{\circ} 00^{\prime} 05.3^{\prime \prime}$ ) the top of granite stone with mosses. Specimens are kept in the Lichenological herbarium, Institute of General and Experimental Biology, Mongolian Academy of Sciences. Optical equipment and test solutions were used for the examination of the specimens. Microscopic

\section{RESULTS AND DISCUSSION}

Heterodermia hypoleuca (Ach.) Treis. Atti Soc. Ital. Sci. Nat.11: 615 (1869) [= Parmelia speciosa f. hypoleuca Ach., Anaptychia hypoleuca (Ach.) A. Massal.]

Basionym: Parmelia speciosa f. hypoleuca Ach., Syn. Lich.: 211 (1814).

Synonym: Anaptychia hypoleuca (Ach.) A. Massal.

Thallus: foliose, irregular to orbicular, up $8 \mathrm{~cm}$ in diametre, loosely adnate with discrete, repeatedly dichotomously or irregularly lobate; Lobes: up to $2 \mathrm{~mm}$ broad, usually around $1 \mathrm{~mm}$, irregularly or dichotomously branched; tips: not ascending, with small adventive lateral lobules, sometimes weak, eciliate; upper surface: greenish white or gray to dark gray or brownish, not or very weakly pruinose; soredia and isidia absent; upper cortex: prosoplectenchymatous; medulla: outskirts of Ulaanbaatar.

The Bogd Uul mountain is located on the banks of the Tuul River that runs through the city. Another place from where Heterodermia hypoleuca (Ach.) Treis was collected in 2013 comes from the Great Khingan floristic districts in the eastern part of Mongolia.

sections of the thalli and fruiting bodies were made by hand and observed under microscope (Carl Zeiss Jena) and digital microscope (XSP-3CB) with Mshot-MD30 camera. The specimens were examined in water, and using $10 \% \mathrm{KOH}$ solution $(\mathrm{K})$, saturated $\mathrm{Ca}(\mathrm{ClO})_{2}$ solution (C) and water solution of potassium iodide $(\mathrm{Kl})$. In the article the taxa are arranged alphabetically, followed by collection locations and substrates. The nomenclature follows resent literature (e.g., Blanco et al., 2004; Eriksson, 2006; Kirk et al., 2008) and the Index Fungorum database (Index..., 2013).

white; lower cortex: absent; lower surface: white to purple or almost black; rhizines: marginal, pale to black.

Apothecia: common, sometimes cup shaped, shortly stipitate or sessile with lobulated margin; disc: brown to dark brown; asci: cylindrical to subclavate, 8-spored; ascospores: brown, 1-septate, ellipsoid, Pachysporaria type, with or without sporoblastia, (22.5-)23.5-30.5 (-35) x 12.5-16 $\mu \mathrm{m}$; Spot tests: cortex K+ yellow C-, KC-, P+ yellow medulla $\mathrm{K}+$ yellow to orange.

Substrate and ecology: growing on bark of a tree with fairly moist trunking and in open condition in the forest of Betula fusca Pall.

Global distribution: Southern North America, Africa and East Asia. China, Korea, Japan, North and South America, East and South Africa, Australia.

Mongolia, Khingan mountain ranges: 
Vol. 59 No 01 (229) 2019
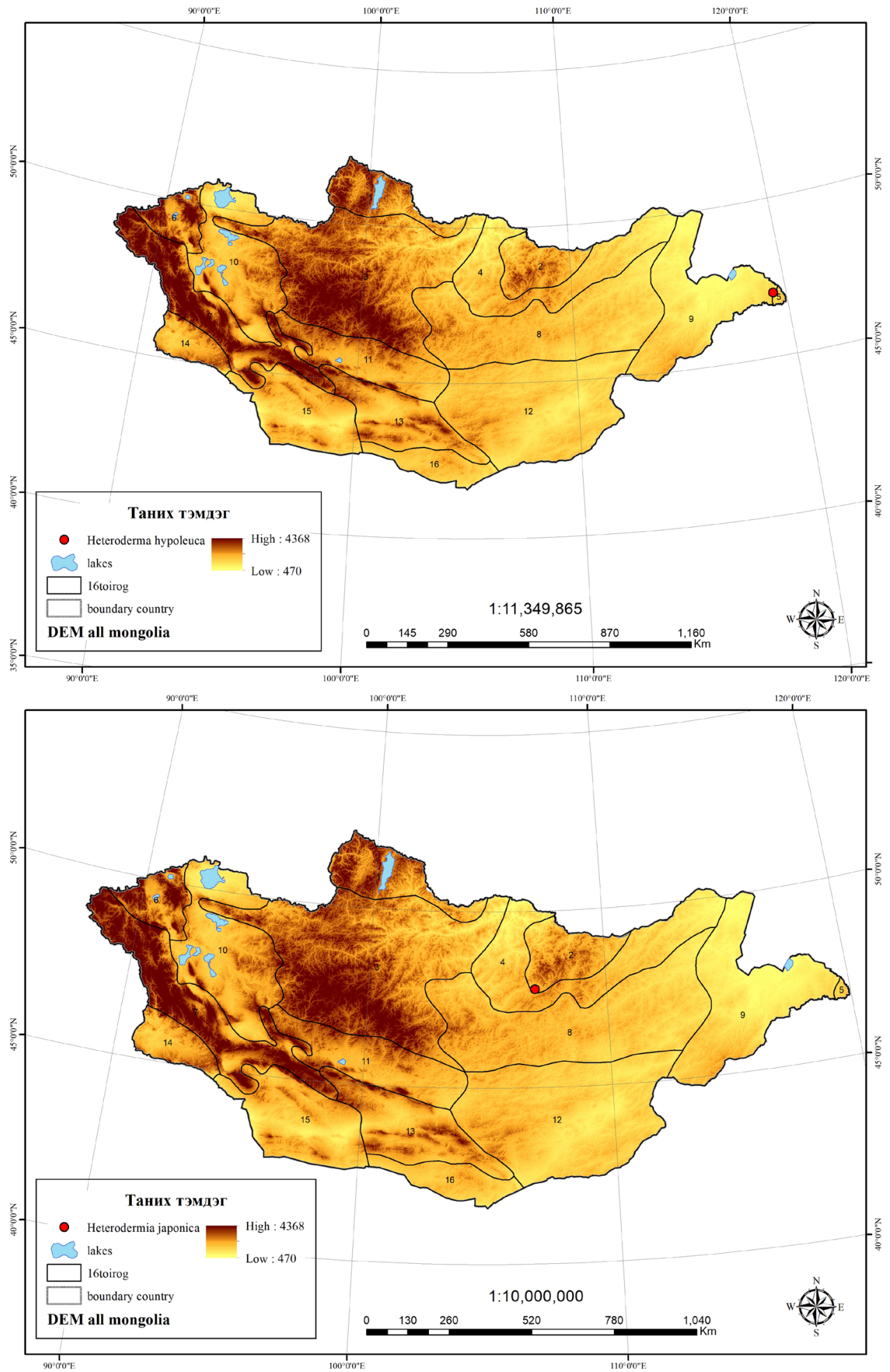
Dornod aimag, Khalha Gol soum, Protected area of Nömrög (N 4745'49.9"; E 10700' 05.3") $937 \mathrm{~m}$ above sea level. Collected by authors on 27.08.2013.

Heterodermia japonica (M. Sato) Swinscow \& Krog, lichenologist 8:122 (1976).

Basionym: Heterodermia dendritica var. japonica Sato, J. Jap.Bot. 12:427 (1936).

Synonyms: Anaptychia dendritica var. japonica M. Satô, Japanese Journal of Botany: 427 (1936); Anaptychia japonica (M. Satô) Kurok., Beiheftezur Nova Hedwigia 6: 58 (1962) [MB\#364143]; Polyblastidium japonicum (M. Satô) Kalb, Phytotaxa 235: 43 (2015) [MB\#813844]; Heterodermia dendritica var. propagulifera (Vain.) Poelt, Heterodermia propagulifera (Vain.) J.P.Dey in Parker \& Roane.

Thallus: foliose, rarely orbicular, usually irregularly spreading, loosely adnate, to 3-5 cm wide. Lobes: $0.5-2.0 \mathrm{~mm}$ wide, to c. $2-4$ $\mathrm{mm}$ wide at the tips, plane to weakly convex or weakly concave, radiating; \pm lobulate along the lobe margins, lobules: \pm rounded or sparingly branched, $0.3-0.6 \mathrm{~mm}$ wide, rarely with small soralia, eciliate.

Upper surface: greenish white, whitish to pale grey, sorediate; soredia: farinose to granular, on lateral and terminal lobes, occasionally spreading along lobe margins.

Medulla: white. Lower surface: ecorticate, arachnoid, white to violet-black in the centre; yellow pigments absent. Rhizines: marginal, black, simple or squarrosely branched.

Apothecia: very rare, margin ecorticate lobulate, apically sorediate; Ascospores:Polyblastidia-type, ellipsoidal, with 2 or 3 small sporoblastidia, $40-45 \times 20$ $23 \mu \mathrm{m}$. Spot tests:Cortex K+ yellow, C-, KC-, $\mathrm{P}+$ yellow; medulla $\mathrm{K}+$ yellow.

Substrate and ecology: Occurs on dead wood and on boulder granite rocks along the coastline of the river Manzushir in shady situations.

Global distribution: Europe, East Asia (East Siberia, Far East) Asia, East-South Africa, North -South America and Australia.
A pantropical and subtropical species.

Mongolia, Khentii: Töv aimag, protected area of Bogd Uul Mountain (N47 $01^{\prime} 004^{\prime \prime}$, E119 $\left.22^{\prime 2} 263^{\prime \prime}\right) 1816 \mathrm{~m}$ above sea level. Collected by author on 27.07.1995.

Heterodermia subascendens (Asahina) Trass, Folia Cryptog. Estonica 29: 20 (1992).

Basionym: Anaptychia subascendens Asahina, J. Jap. Bot. 33: 325 (1958). T: Kubota, Kaya-mati, Misima, Prov. Izu, Japan, July 1929, Y. Asahina 208; holo: TNS.

Thallus: foliose, forming small rosettes or irregularly spreading, adnate to loosely adnate, 3-5 cm wide. Lobes: 0.5-3.0 $\mathrm{mm}$ wide, sublinear, but widening up to $5 \mathrm{~mm}$ at the tips, spathulate or paddle-shaped, weakly convex, dichotomously or irregularly branched, suberect or ascending, \pm with marginal rhizines that are visible from above.

Upper surface: greyish white or greenish grey, epruinose, sorediate on the undersides of lobe apices.

Medulla: white. Lower surface: ecorticate, arachnoid, \pm reticulately veined in the centre, variegated white and yellow, rhizines: simple, becoming sparsely branched, darkening at the apices.

Apothecia: margin sorediate, not seen in Mongolian material but reported to be very rare (Kurokawa, 1962), eciliate; disc: dark brown, weakly white-pruinose.

Ascospores: Polyblastidia-type, ellipsoidal, with 2 or 3 small sporoblastidia, 34-41 × 16-20 $\mu \mathrm{m}$. Spot tests: Cortex K+ yellow, $\mathrm{C}-, \mathrm{KC}-, \mathrm{P}+$ yellow; medulla $\mathrm{K}+$ yellow, $\mathrm{C}-, \mathrm{P}-$ or $\mathrm{P}+$ pale yellow; yellow pigment on lower surface $\mathrm{K}+$ violet.

Substrate and ecology: Occurs on barkand on boulder granite rocks along the coastline of the river Manzushir in shady situations.

Global distribution: East Asia (Siberia, Far East, South Korea, Japan and Taiwan).

Mongolia, Khentii: Töv aimag, protected area of Bogd Uul Mountain (N47001'004", E119022'263") $1816 \mathrm{~m}$ above sea level. Collected by author on 27.07.1995. 


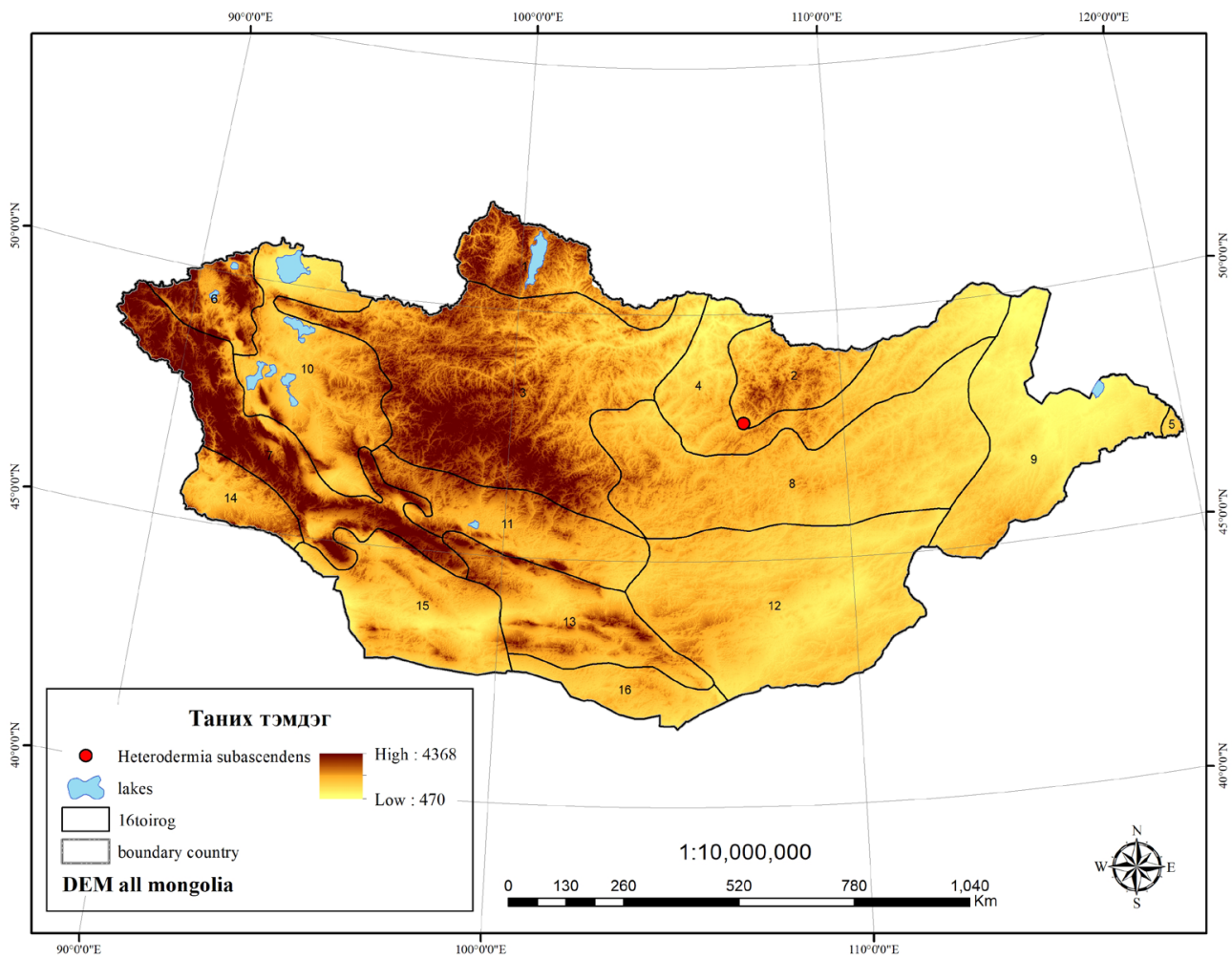

Kurokawa (1962) published a definitive world monograph of the genus Anaptychia in which 72 predominately tropical species were treated. Subsequently, that genus was recognized as heterogeneous by Poelt (1965), who separated the genus Heterodermia with smooth, thick-walled spores and the constant occurrence of atranorin in the upper cortex from Anaptychia, all species of which have Physconia-type spores and lake atranorin in the upper cortex. That's way some of Kurokawa's originally recognised species have been transferred to Heterodermia. This delimitation is now widely accepted and also by Kurokawa (1998).

As well as, Heterodermia is most similar to Physcia in size and colour. It differs mainly in the structure of the upper cortex (pseudoparenchyma in Physcia), and spore type (primarily Physcia-type spores in Physcia). The structure of the upper cortex in Heterodermia gives the surface the appearance of flowing toward the lobe tips, whereas the upper surface in Physcia has a uniform, unoriented appearance [6].

Heterodermia hypoleuca is characterised by the sorediate upper surface, \pm radiating lobe apices, the absence of a lower cortex, white to blackish violet lower surface, ascospores with sporoblastidia and the presence of atranorin and triterpenes. This fringe lichen is much like $H$. speciosa but without soredia. Also Heterodermia rugulosa is a southwestern species similar to $H$. hypoleuca, but its upper surface can be quite pruinose, and its lower surface is smooth and with cortex.

Heterodermia japonica is characterised by the sorediate upper surface, \pm radiating lobe apices, the absence of a lower cortex, white to blackish violet lower surface, ascospores with sporoblastidia and the presence of atranorin and triterpenes.

Heterodermia subascendens is characterised by the ascending or suberect 
lobes with marginal, sublabriform soralia and spathuliform apices, white, ecorticate lower surface with yellow spots $(\mathrm{K}+$ purple), ascospores with sporoblastidia, and the presence of atranoin, zeorin and skyrin [34].

Interestingly, the Bogd Uul Mountain, where H. japonica and H.subascendens were registered, is one of the fragmented regions of permafrost replete with river granite stone, which is one of the main elements of the relief formation of the are. Although the lichen biota of the protected Bogd Uul Mountain has been
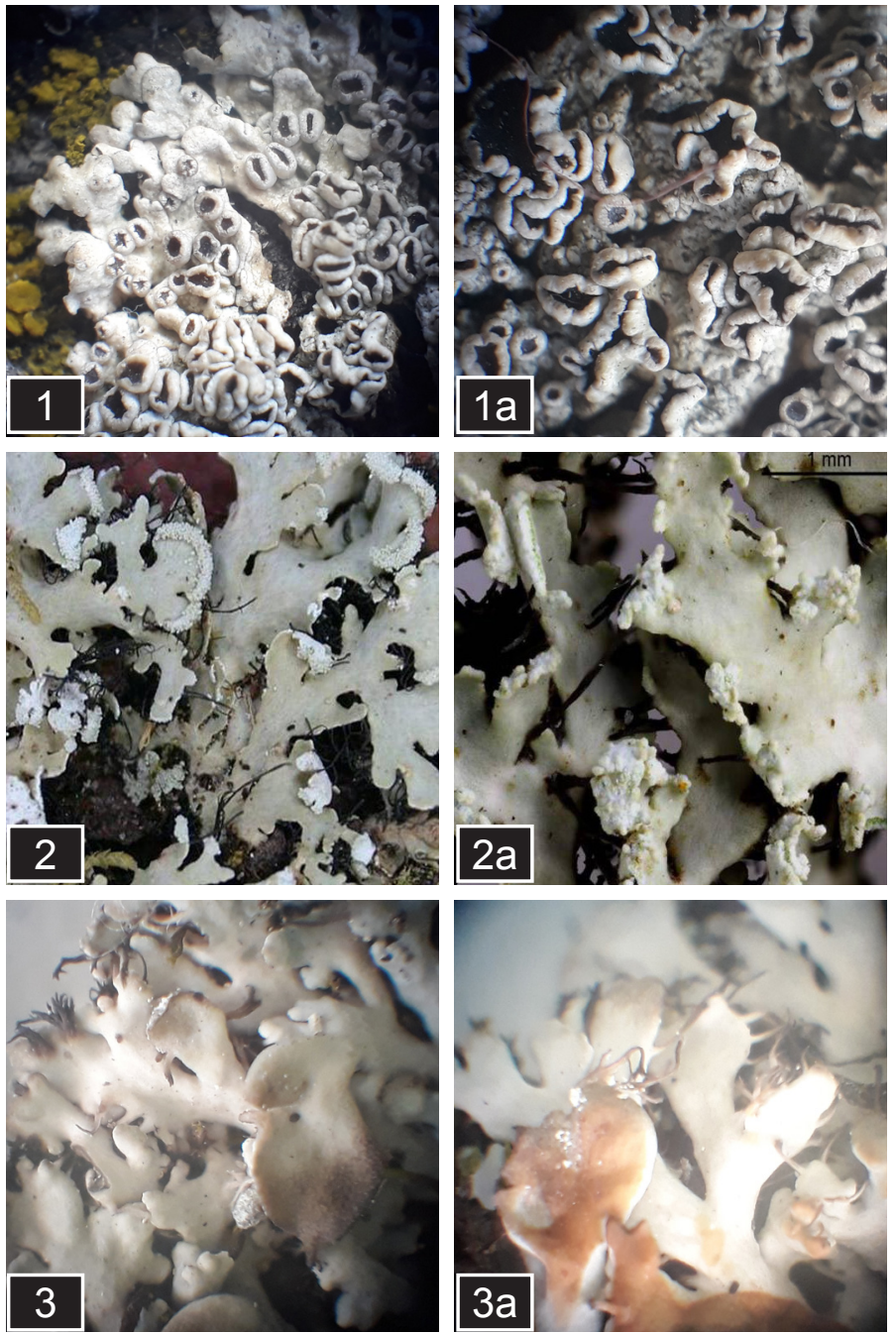

studied quite well, one of its most unique characteristics are the species widespread in the boreal mountain area [8]. The lichen biota in the forests of Larix sibirica, Pinus selvestris, Piceao bovata and Betula plantyphylla of this protected mountain are similar to almost all the species occurring also in other northern Mongolian mountainsous especially Khentii Mountain region in northeast Mongolia.

Heterodermia hypoleuca is characteristic to the eastern part of Mongolia. It is widespread in the eastern part Russia, China, Korea, Japan

Picture 1. Heterodermia hypoleuca (Ach.) Treis. The upper (1a) and lower (1b) surface of the thalli. Picture 2. Heterodermia japonica (M. Sato) Swin. \& Krog. The upper (2a) and lower (2b) surface of the thalli. Picture 3. Heterodermia subascendens( Asahina) Trass. The upper (3a) and lower (3b) surface of the thalli. 
North and South America, East and South Africa and Australia [18]. At the present stage of geological history, when higher vascular plants cannot point to the ancient relations between the flora of far-away regions, lichens convincingly demonstrate that such connections and relationship do exist.

Moreover, it is possible to assume with a high degree of certainty that some species of
Heterodermia are also found in North-Eastern Mongolia and North-East China, which border with Southeast Transbaikalia. Similar ranges of these species of Heterodermia indicate ancient floristic connections between Baikal Siberia and the Mediterranean, which were connected by the common space of the formation of the arid desert-steppe Eurasian-North-African flora [31].

\section{CONCLUSIONS}

A study on taxonomy of some species of Heterodermia in Mongolia is presented. Phenotypic analysis was based on morphological, anatomical, and chemical characters. The results suggest that the genus Heterodermia is monophyletic. Some characters (e.g. corticate vs. ecorticate lower surface, absence vs. presence of yellow pigments or soredia) are shown to be taxonomically significant within the genus.
Of the five species of Heterodermia known to occur in Mongolia, three were confirmed in this study.

Acknowledgments: This work was supported by the Mongolian Scientific and Technological Foundation through the Mongolian Ministry of Education, Science, Culture and Sports under the project "The impact of climate change on the flora of Mongolia “ (2017-2019).

\section{REFERENCES}

[1] Abbas, A., Mijit, A., Tömör, A. \& Jinong, W., (2001). A Checklist of the Lichens of Xinjiang, China. Harvard Papers in Botany 5: pp. 359-370.

[2] Biazrov, L. G., (1976). Lishajnikovye sinuzii v listvennichnike s ivojosokovo-zlakovolugovoraznotravnom(Khangajskij khrebet, MNR)//Bjulleten'Moskovskogo ObshchestvaIspytatalej Prirody. Otdel Biologicheskij. 81(6) :pp. 112-122.

[3] Biazrov, L. G., Ganbold, E., Gubanov, I. A., Ölzijkhutag, N., (1989). Flora Khangaya. - Leningrad: Nauka. p. 191.

[4] Biazrov, L. G., Gubanov, I. A., Ganbold, E., Dul'gerov, A. N., Tsegmed, C. (1993). Flora Vostochnogo Khangaya (MNR). Moskva: Nauka. p.185.

[5] Biazrov, L. G,. (2013). Composition of Lichen Species of Mongolia and Its Distribution on Floristic Districts of the Country, biaz@genome.eimb.relarn.ru,

[6] Brodo, I. M., (2001). Lichens of the North America. Yale University Press. p. 795.

[7] Tsogt, U., (1995). Die Flechten der Mongolei. Willdenowia. 25 (1), pp. 289-397.

[8] Enkhtuya, O., (2007). Lichens of Bogd Uul Mountain. Ulaanbaatar. Bembisan. p. 232. (in Mongolian).

[9] Golubkova, N. S., (1981). Konspect Flory Lishajnikov Mongol'skoj Narodno Respupliki. Leningrad: Nauka. p. 200.

[10] Golubkova, N. S., (1983). Analiz florylishajnikov Mongolii. Leningrad: Nauka. p. 248.

[11] Hauck, M., Javkhlan, S., Lkhagvadorj D., Bayartogtokh, B., Dulamsüren, C., Leuschner, C., (2012). Edge and Land-use Effects on Epiphytic Lichen Diversity in the Forest-Steppe Ecotone of the Mongolian Altai. Flora. V (207): pp. 450-458.

[12] Hauck, M., Tinsberg, T., Mayrhofer, H., de Bruyn, U., Enkhtuya, O., Javkhlan, S., (2013). New Records of Lichen Species from Western Mongolia. Folia Cryptog. Estonica. Fasc. 50, pp. 13-22.

[13] Huneck, S., Ahti, T., Tsogt, U., Poelt, J., Sipman, H., (1992). Zur Verbreitung und Chemie von 
Flechten der Mongolei. III. Ergebnisse der Mongolisch-Deutschen Biologischen Expedition seit 1962 Nr. 217. Nova Hedwigia. Bd. 54 (3-4), pp. 277-308.

[14] Zhurbenko, M. P., (2009). Lichenicolous Fungi and Some Lichens from the Holarctic. Opuscula Philolichenum. 6: pp. 87-120.

[15] Zhurbenko, M., (2010). Lichenicolous Fungi and Lichens Growing on Stereocaulon from the Holarctic, with a Key to the Known Species. Opuscula Philolichenum.8: pp. 9-39.

[16] Zhurbenko, M. P., \& Alstrup, V., (2004). Lichenicolous Fungi on Cladonia Mainly from the Arctic. Acta Univ. Ups. Symb. Bot. Ups. 34 (1), :pp. 477-499.

[17] Zhurbenko, M.P., Triebel, D., (2008). Three New Species of Stigmidium and Sphaerellothecium (lichenicolous ascomycetes) on Stereocaulon. Mycol Progress.7, pp.137-145.

[18] Key to Lichens of Russia. SPb.:Nauka, 2008. 10: p. 515.

[19] Kudratov, I., \& Mayrhofer, M., ( 2002). Catalogue of the Lichenised and Lichenicolous Fungi of Tajikistan. Herzogia15 : pp. 91-128.

[20] Kurokawa, S., (1962). A Monograph of the Fenus Anaptychia, Beih. Nova Hedwigia 6: pp. 1-115.

[21] Kurokawa, S., (1998). A Catalogue of Heterodermia, Folia Cryptog. Estonica 32: pp. 21-25.

[22] Litterskii, B., (2006). Foliose and Fruticose lichens of Kyrgyzstan. Herzogia19, pp. 177-190.

[23] Moberg, R., (2004). The Lichen Genus Heterodermia in Europe and the Macaronesian Islands, Biblioth. Lichenol. 88, pp. 453-463.

[24] Moberg, R., \& Nash III, T.H., (2002). The Genus Heterodermia in the Sonoran Desert Area, Bryologist 102, pp. 1-14.

[25] Moberg, R., \& Nash III, T.H., (2002).Heterodermia, Lichen Fl. Greater Sonoran Desert Region 1, pp. 207-219.

[26] 'Moberg, R., \& O.W. Purvis, (1997). Studies on the Lichens of the Azores. Part 4. The genus Heterodermia, Symb. Bot. Upsal. 32(1), pp. 187-194.

[27] Poelt, J., (1965). Zur Systematik der Flechtenfamilie Physciaceae. Nova Hedwigia 9, pp.21-32.

[28] Swinscow, T. D. V.; Krog, H., (1976). The General Anaptychia and Heterodermia in East Africa. The Lichenologist. 8(2), pp.103-138.

[29] Trevisan, V., (1868). Sulgenere Dimelaena di Norman. Attidella SocietàItaliana di Scienze Naturali. 11, pp. 604-630.

[30] Trass, H., (1992). Synopsis of the Lichen Genus Heterodermia (Ascomycotina, Physciaceae sive Pyxinaceae). Folia Cryptogamica Estonica. 29, pp. 2-24.

[31] Trass, H., (2000). The Lichen Genus Heterodermia (Lecanorales, Physciaceae) in Russia and Adjacent Territories, Folia Cryptog. Estonica 37, pp. 93-108.

[32] Wagner, V., \& Spribille, T., (2005). Preliminary Checklist of the Lichens Kazakhstan. 1 July 2005. http://www.geobotanik.org

[33] Wei, J. C., 1991. An Enumeration of Lichens in China. International Academic Publishers, Beijing.

[34] Wei, X. L., Luo, H., Koh, Y. J. \& Hur, J. S., (2008), A Taxonomic Study of Heterodermia (Lecanorales, Ascomycota) in South Korea Based on Phenotypic and Phylogenetic Analysis, Mycotaxon 105, pp. 65-78.Referense. 